\title{
Under-recognized Hypoparathyroidism in Thalassemia
}

\author{
(1) Hataitip Tangngam ${ }^{1}$, (1) Pat Mahachoklertwattana ${ }^{1}$, (1) Preamrudee Poomthavorn ${ }^{1}$, (1) Ampaiwan Chuansumrit ${ }^{1}$, \\ (1) Nongnuch Sirachainan ${ }^{1}$, (1) La-or Chailurkit ${ }^{2}$, (1) Patcharin Khlairit ${ }^{1}$ \\ ${ }_{1}^{1}$ Mahidol University Faculty of Medicine, Ramathibodi Hospital, Department of Pediatrics, Bangkok, Thailand \\ 2Mahidol University Faculty of Medicine, Ramathibodi Hospital, Department of Medicine, Bangkok, Thailand
}

\section{What is already known on this topic?}

Symptomatic hypoparathyroidism in patients with transfusion-dependent thalassemia is relatively rare. Data on prevalence of asymptomatic hypoparathyroidism are also scanty.

\section{What this study adds?}

Hypoparathyroidism in patients with thalassemia is not uncommon. In comparison with patients with normoparathyroidism, plasma fibroblast growth factor 23 was lower in patients with hypoparathyroidism. Screening for asymptomatic mild hypocalcemia without elevation of parathyroid hormone should be considered in transfusion-dependent thalassemia for early detection and proper treatment.

\begin{abstract}
Objective: Symptomatic hypoparathyroidism [symptomatic hypocalcemia without elevated serum parathyroid hormone (PTH)] in patients with thalassemia is relatively rare. Asymptomatic mild hypocalcemia without elevated PTH, which is considered hypoparathyroidism, may be more common but under-recognized.

Methods: Sixty-six transfusion-dependent thalassemic patients and 28 healthy controls were enrolled. Serum calcium (Ca), phosphate (P), creatinine (Cr), albumin, intact PTH, 25-hydroxyvitamin D (25-OHD), plasma intact fibroblast growth factor-23 (FGF-23), urinary Ca, $\mathrm{P}$ and $\mathrm{Cr}$ were measured. Tubular reabsorption of $\mathrm{P}$ was calculated.

Results: Thalassemic patients had significantly lower median serum Ca levels than the controls [8.7 (7.8-9.7) vs 9.6 (8.7-10.1) mg/ $\mathrm{dL}, \mathrm{p}<0.001]$. Hypoparathyroidism was found in 25 of 66 (38\%) patients. Symptomatic hypoparathyroidism was not encountered. Thalassemic patients also had significantly lower median plasma FGF-23 levels than the controls [35.7 (2.1-242.8) vs 53.2 (13.3218.6) $\mathrm{pg} / \mathrm{mL}, \mathrm{p}=0.01]$. In patients with hypoparathyroidism, median plasma FGF-23 level was significantly lower than that of normoparathyroid patients [34.8 (2.1-120.0) vs $43.1(3.2-242.8) \mathrm{pg} / \mathrm{mL}, \mathrm{p}=0.048]$. However, serum P, Cr, intact PTH and 25-OHD levels were not significantly different in the two groups.

Conclusion: Hypoparathyroidism was not uncommon in patients with transfusion-dependent thalassemia treated with suboptimal iron chelation. Plasma intact FGF-23 level in hypoparathyroid patients was lower than that of normoparathyroid patients.
\end{abstract}

Keywords: Thalassemia, hypoparathyroidism, hypocalcemia, iron overload, fibroblast growth factor-23

\section{Introduction}

Thalassemia is an inherited disease caused by abnormal hemoglobins. It leads to ineffective erythropoiesis and increased peripheral hemolysis. Regular blood transfusion is inevitable in patients with moderate to severe thalassemia. Overt hypoparathyroidism in thalassemia is relatively rare (1). However, asymptomatic hypoparathyroidism has been rarely reported, although its incidence was as high as $42 \%$ in one study (2). Previous studies have shown that hypoparathyroidism was primarily associated with iron overload $(3,4,5,6)$.

Relatively high serum phosphate (P) levels in children and adults with thalassemia were reported in several studies $(7,8,9,10)$. Our previous study also demonstrated that serum $P$ levels in transfusion-dependent thalassemia had a trend to be higher than those in non-transfusion 
dependent thalassemia cases, but not significantly so $(p=0.081)$ (11). In transfusion-dependent thalassemia, high $\mathrm{P}$ loading due to regular blood transfusions, hemolysis and hypoparathyroidism contribute to elevated serum P levels (12).

Fibroblast growth factor-23 (FGF-23), a phosphaturic hormone, is mainly synthesized and secreted by osteoblasts and osteocytes in response to hyperphosphatemia and elevated 1.25-dihydroxyvitamin $\mathrm{D} \quad\left(1.25-(\mathrm{OH})_{2} \mathrm{D}\right)$ concentration (13). FGF-23 acts at the renal tubular cell level to reduce $\mathrm{P}$ reabsorption. In addition, FGF-23 inhibits $1 \alpha$-hydroxylase, leading to a reduction in formation of 1.25-(OH) ${ }_{2} \mathrm{D}$ (14). FGF-23 also reduces parathyroid hormone (PTH) secretion from the parathyroid glands, thereby attenuating the PTH-mediated phosphaturic effect (15). However, the mode of FGF-23- $\mathrm{P}$ axis control in thalassemia has not been elucidated.

Our previous histomorphometric study demonstrated that iron deposits in thalassemic bones impaired bone mineralization and reduced bone formation (16). In vitro studies demonstrated that excessive iron inhibited osteoblast proliferation and differentiation $(17,18)$. Therefore, iron accumulation in thalassemic bones may compromise FGF23 production by osteoblasts and osteocytes.

We therefore hypothesized that asymptomatic hypoparathyroidism might be common but underrecognized in patients with thalassemia. In addition, impaired FGF-23 production, secondary to iron deposits in bones, might partly contribute to elevated serum $\mathrm{P}$ in thalassemia. Our study aimed to determine serum calcium (Ca), P and 25-hydroxyvitamin D (25-OHD), PTH and plasma FGF-23 levels in transfusion-dependent thalassemic patients.

\section{Methods}

Children and adolescents with transfusion-dependent thalassemia attending the Hematology Clinic at the Department of Pediatrics, Faculty of Medicine, Ramathibodi Hospital, Mahidol University, Bangkok, Thailand were enrolled in the study. Most of these transfusion-dependent thalassemic patients had received a standard regular blood transfusion therapy every 3-4 weeks to maintain their hemoglobin levels at 9-10.5 g/dL. Desferrioxamine was the only iron chelating agent used in patients who had a serum ferritin level greater than $1000 \mathrm{ng} / \mathrm{mL}$. Additional oral iron chelators such as deferiprone and deferasirox have been used in the past five years. All patients received daily folic acid and multivitamin supplementation. Each tablet of multivitamin contains $400 \mathrm{IU}$ of vitamin $\mathrm{D}_{2}$. Patients with known underlying conditions including hypoparathyroidism, renal disease and acute hemolysis, and patients who had been taking other medications affecting $\mathrm{Ca}, \mathrm{P}$ and vitamin D metabolism, were excluded. The controls were healthy children who attended the day camp regularly arranged by our hospital during the end of each school semester. All these controls were the offspring of hospital personnel. None of them had been taking medications known to affect $\mathrm{Ca}, \mathrm{P}$ and vitamin D metabolism.

Anthropometric measurements were performed at the time of enrollment. Measurements included weight to the nearest $0.1 \mathrm{~kg}$ measured using a digital weighing scales; height to the nearest $1 \mathrm{~mm}$, measured using a Harpenden stadiometer (Holtain Ltd, Crymych, Dyfed, Wales). Z-scores of height and weight were calculated using the National Standard Growth Curve of the Ministry of Public Health, Thailand. The Z-score of body mass index (BMI) was calculated using the World Health Organization BMI for age and sex. Median serum ferritin was determined using serum ferritin levels periodically obtained during routine clinic visits. Cumulative iron loading was estimated from cumulative volume of packed red cell (PRC) transfusion as follows:

Cumulative iron loading $(\mathrm{mg})=$ volume $(\mathrm{mL})$ of PRC given $\mathrm{x}$ hematocrit of PRC x 1.16 (19).

Fasting blood samples were obtained in thalassemic patients and controls for determination of serum $\mathrm{Ca}, \mathrm{P}, \mathrm{Cr}$, albumin, intact PTH, 25-OHD and plasma intact FGF-23 levels. In thalassemic patients, fasting blood samples were obtained on the day of transfusion just before the scheduled transfusion. Simultaneous spot morning urine samples for $\mathrm{Ca}, \mathrm{P}$ and $\mathrm{Cr}$ in thalassemic patients were obtained. Serum PTH and 25-OHD were measured by chemiluminescence assay (Roche Diagnostics GmbH, Mannheim, Germany). Corrected serum $\mathrm{Ca}$, tubular reabsorption of $\mathrm{P}$ (TRP) and ratio of tubular $\mathrm{P}$ (TP) reabsorption to the glomerular filtration rate (TP/GFR) were calculated using the following formulas:

Corrected serum $\mathrm{Ca}(\mathrm{mg} / \mathrm{dL})=$ Total serum $\mathrm{Ca}(\mathrm{mg} / \mathrm{dL})+$ $0.8 \times[4-$ serum albumin $(\mathrm{g} / \mathrm{dL})]$

$\operatorname{TRP}(\%)=\{1-[($ urine $\mathrm{P} /$ serum $\mathrm{P}) /$ (urine $\mathrm{Cr} /$ serum Cr) $]\} \times 100$

TP/GFR $(\mathrm{mg} / \mathrm{dL})=$ Serum $\mathrm{P}-$ (urine $\mathrm{P} \times \mathrm{x}$ serum $\mathrm{Cr} /$ urine Cr) (20)

Definitions used in this study: Hypocalcemia $=$ corrected serum $\mathrm{Ca}<8.5 \mathrm{mg} / \mathrm{dL}$; normocalcemia = corrected serum Ca 8.5-10.4 mg/dL; hypoparathyroidism = hypocalcemia without elevated intact PTH (reference range: 20-75 pg/mL). 
Plasma intact FGF-23 was measured in duplicate by a commercial the enzyme-linked immunosorbent assay (ELISA) kit (2nd generation human intact FGF-23 ELISA kit, (Immutopics Inc, San Clemente, CA). The intra-assay coefficient of variation (CV) was $2.0-4.1 \%$ and the interassay CV was 3.5-9.1\%. The lower limit of detection was $1.5 \mathrm{pg} / \mathrm{mL}$.

The study was approved by the Ethics Committee of the Faculty of Medicine, Ramathibodi Hospital, Mahidol University (ethics approval no. MURA2013/24 Np1). Informed consent was obtained from the patients and their legal guardians.

\section{Statistical Analysis}

Statistical analyses were performed using the software package SPSS 15.0 (SPSS, IBM Inc., Chicago, USA). All parameters were not normally distributed determined by Kolmogorov-Smirnov test and therefore, they were presented as median (range). Comparison between the patient and control groups was performed using Mann-Whitney U test. Pearson's correlation was used to determine the correlation between two variables. A p value of less than 0.05 was considered statistically significant.

\section{Results}

Sixty-six transfusion-dependent thalassemic patients, with a median (range) age of 13.5 (5.1-23.2) years, and 28 healthy controls, median (range) age of 8.9 (4.8-17.2) years participated in the study. Sixty of these patients were $\beta$-thalassemia/hemoglobin E ( $\beta$-thal/E) cases and six were patients with $\beta$-thalassemia homozygote ( $\beta$-major) disease. Twelve patients were splenectomized. All patients had been receiving monthly PRC transfusions and iron chelation therapy, including desferrioxamine in combination with either deferiprone or deferasirox. In comparison with the controls, thalassemic patients were significantly older, but their Z-scores for weight, height and BMI were lower. Thalassemic patients had significantly lower corrected serum $\mathrm{Ca}$ and plasma intact FGF-23 levels than those of the controls. No significant differences in serum P, PTH and 25OHD levels were found between the two groups (Table 1). There were no significant differences in corrected serum Ca, P, 25-OHD, PTH and plasma intact FGF-23 levels between patients with $\beta$-thal/E and $\beta$-major. Hypoparathyroidism (corrected serum Ca 7.5-8.4 mg/dL and no elevation of PTH) was found in 25 of 66 (38\%) thalassemic patients. None of the controls had hypocalcemia. Most thalassemic patients (94\%) had normal vitamin D status (25-OHD $\geq 20 \mathrm{ng} / \mathrm{mL}$ ). Only 4 of $66(6 \%)$ patients (3 $\beta$-thal/E, $1 \beta$-major) had mild vitamin D insufficiency (25-OHD, range 18.6-19.7 ng/mL). All but one of the controls (27 of 28) had normal vitamin D status (one child had mild vitamin D insufficiency, 25-OHD $16.8 \mathrm{ng} / \mathrm{mL})$.

Twenty-five thalassemic patients had asymptomatic mild hypocalcemia. All these patients who had either an inappropriately low or normal serum PTH were considered to have hypoparathyroidism. The

\begin{tabular}{|c|c|c|c|}
\hline $\begin{array}{l}\text { Parameters } \\
\text { Median (range) }\end{array}$ & Thalassemic $(n=66)$ & Control $(n=28)$ & $\mathrm{p}$ value \\
\hline Age (years) & $13.5(5.1-23.2)$ & $8.9(4.8-17.2)$ & 0.004 \\
\hline Male, n (\%) & $35(53)$ & $10(36)$ & NS \\
\hline Z-score of weight & $-0.8(-3.2$ to 2.6$)$ & $+0.8(-1.5$ to 5.4$)$ & $<0.001$ \\
\hline Z-score of height & $-0.7(-4.0$ to 2.0$)$ & $+0.2(-1.4$ to 0.8$)$ & $<0.001$ \\
\hline Z-score of BMI & $-0.6(-3.6$ to 2.3$)$ & $+0.2(-0.8$ to 3.3$)$ & 0.016 \\
\hline Puberty, n (\%) & $39(59)$ & $11(39)$ & $<0.001$ \\
\hline Corrected serum calcium (mg/dL) & $8.7(7.8-9.7)$ & $9.6(8.7-10.1)$ & $<0.001$ \\
\hline Serum phosphate (mg/dL) & $4.9(3.8-6.2)$ & $4.9(4.1-6.0)$ & NS \\
\hline Serum creatinine (mg/dL) & $0.4(0.2-0.8)$ & $0.4(0.2-0.8)$ & NS \\
\hline Serum PTH (pg/mL) & $31.5(12.5-74.6)$ & $29.6(20.5-65.8)$ & NS \\
\hline Serum 25-OHD (ng/mL) & $27.6(18.6-57.3)$ & $26.6(16.8-38.7)$ & NS \\
\hline Plasma FGF-23 (pg/mL) & $35.7(2.1-242.8)$ & $53.2(13.3-218.6)$ & 0.010 \\
\hline Hemoglobin (g/dL) & $8.6(5.9-11.0)$ & - & - \\
\hline Serum ferritin (ng/mL) & $1,333(372-6,752)$ & - & - \\
\hline
\end{tabular}


remaining 41 patients had normal serum $\mathrm{Ca}$ and $\mathrm{PTH}$ levels. There were no significant differences in gender, age, Z-scores of weight, height and BMI and ages of onset of transfusion and chelation therapy between patients with hypoparathyroidism and those with normoparathyroidism. In the hypoparathyroid group, the lowest level of 25-OHD was $18.6 \mathrm{ng} / \mathrm{mL}$; almost all patients had vitamin D sufficiency (median $27.6 \mathrm{ng} / \mathrm{mL}$ ). In comparison with normoparathyroid patients, median plasma intact FGF-23 was slightly but significantly lower in the hypoparathyroid group (43.1 vs 34.8 pg/ $\mathrm{mL}, \mathrm{p}=0.048)$. There were no significant differences in the serum $P$ levels of these two groups. Cumulative iron loading was greater, while serum ferritin was lower in the hypoparathyroid group (Table 2). Serum Ca level had a negative correlation with duration of transfusions in hypoparathyroid patients $(r=-0.45, p=0.022)$, but had no correlation in the normoparathyroid group.

\section{Discussion}

The present study demonstrates asymptomatic hypoparathyroidism in transfusion dependent thalassemia. Previous studies reported low prevalences of hypoparathyroidism, ranging from 0.5 to $7.6 \%$ $(5,12,21)$. Those prevalences primarily represented overt or symptomatic hypoparathyroidism. This crosssectional study looked at Ca-P metabolism in patients with transfusion-dependent thalassemia. No patients had symptoms of hypocalcemia or a history of fractures. The prevalence of hypoparathyroidism was $38 \%$ in this study, which suggests a high prevalence of unrecognized, asymptomatic hypoparathyroidism. This is in line with previous studies of Mostafavi et al (22) and Adil et al (23) that reported hypoparathyroidism in $22.7 \%$ and $35.3 \%$ of thalassemic patients, respectively. Previous studies demonstrated that hypoparathyroidism was associated with high serum ferritin levels $(3,4,5,6)$. A serum ferritin level higher than 2,500-3,000 $\mathrm{ng} / \mathrm{mL}$ has been demonstrated to be associated with higher frequency of hypoparathyroidism $(5,6)$. In addition, Belhoul et al (6) also reported that patients with a serum ferritin $>2,500-3,000 \mathrm{ng} / \mathrm{mL}$ were 3.27 times more likely to develop hypoparathyroidism. However, no relationship between hypoparathyroidism and serum ferritin has been reported $(24,25)$. In the present study, the patients had modestly elevated, median serum ferritin level of $1333 \mathrm{ng} / \mathrm{mL}$ and the median serum ferritin level in

\begin{tabular}{|c|c|c|c|}
\hline $\begin{array}{l}\text { Parameters } \\
\text { Median (range) }\end{array}$ & Hypoparathyroid* $(n=25)$ & Normoparathyroid * $(n=41)$ & $\mathrm{p}$ value \\
\hline Male, n (\%) & $15(60)$ & $20(49)$ & NS \\
\hline Age (years) & $14.2(7.3-18.9)$ & $11.8(5.1-23.2)$ & NS \\
\hline Z-score of weight & $-0.8(-1.9$ to 2.3$)$ & $-0.7(-3.2$ to 2.6$)$ & NS \\
\hline Z-score of height & $-0.9(-2.4$ to 1.6$)$ & $-0.5(-4.0$ to 2.0$)$ & NS \\
\hline Z-score of BMI & $-0.8(-2.9$ to 2.3$)$ & $-0.5(-3.6$ to 1.4$)$ & NS \\
\hline Puberty, n (\%) & $18(72)$ & $20(49)$ & 0.030 \\
\hline Corrected serum calcium (mg/dL) & $8.2(7.8-8.4)$ & $8.9(8.5-9.7)$ & $<0.001$ \\
\hline Serum phosphate (mg/dL) & $4.9(4.0-5.8)$ & $5.1(3.8-6.1)$ & NS \\
\hline Serum creatinine $(\mathrm{mg} / \mathrm{dL})$ & $0.4(0.2-0.8)$ & $0.4(0.2-0.7)$ & NS \\
\hline Serum PTH (pg/mL) & $31.8(15.3-74.6)$ & $31.3(12.5-57.5)$ & NS \\
\hline Serum 25-OHD (ng/mL) & $28.9(18.6-57.3)$ & $27.4(19.4-43.9)$ & NS \\
\hline Plasma FGF-23 (pg/mL) & $34.8(2.1-120.0)$ & $43.1(3.2-242.8)$ & 0.048 \\
\hline Urine $\mathrm{Ca} / \mathrm{Cr}$ (mg/mg) & $0.08(0.01-0.28)$ & $0.06(0.01-0.51)$ & NS \\
\hline $\operatorname{TRP}(\%)$ & $95.6(88.6-99.1)$ & $96.2(87.8-98.6)$ & NS \\
\hline TP/GFR (mg/dL) & $4.7(3.8-5.6)$ & $4.9(3.7-5.9)$ & NS \\
\hline Serum ferritin $(\mathrm{ng} / \mathrm{mL})$ & $1,087(372-6.197)$ & $1,957(449-6.752)$ & 0.001 \\
\hline Cumulative iron loading (g) & $26.8(3.7-60.8)$ & $17.3(3.6-62.9)$ & 0.046 \\
\hline
\end{tabular}

Data are presented as median (range), otherwise as indicated.

*Corrected serum calcium < $8.5 \mathrm{mg} / \mathrm{dL}$; * Corrected serum calcium 8.5-10.4 mg/dL.

PTH: parathyroid hormone, 25-OHD: 25-hydroxyvitamin D, FGF-23: fibroblast growth factor-23, Ca/Cr: calcium to creatinine ratio, TRP: tubular reabsorption of phosphate, TP/GFR: ratio of tubular phosphate reabsorption to glomerular filtration rate, NS: not significantly different 
patients with hypoparathyroidism was lower than that of normoparathyroid patients. This finding can be explained by recent additional iron chelation treatment with oral deferiprone and deferasirox. Iron chelation improved strikingly with this treatment, resulting in rapid reduction of serum ferritin. However, tissue iron accumulation may still persist to a degree. In fact, serum ferritin levels were greater than 3,000 $\mathrm{ng} / \mathrm{mL}$ in our transfusion-dependent thalassemics during the past 5-10 years when only desferrioxamine injection had been used (11).

Previous studies also demonstrated that serum ferritin may not be a reliable indicator of tissue iron overload $(24,26)$. In patients with suboptimal iron chelation therapy, the amount of iron from PRC transfusion may better reflect tissue iron accumulation (27). Hence, our patients with hypoparathyroidism had higher cumulative iron loading than the normoparathyroid patients, despite lower serum ferritin levels. The cause of hypoparathyroidism is likely due to iron deposition in parathyroid glands, as previously reported $(1,24,28,29)$.

FGF-23 is a phosphaturic hormone secreted by osteoblasts and osteocytes in response to elevated serum $P$. Elevated serum FGF-23 levels have been demonstrated in hypoparathyroid patients secondary to other causes such as parathyroidectomy, thyroidectomy or accidental parathyroidectomy and transient hypoparathyroidism in the offspring of hyperparathyroid mothers $(30,31,32)$. In contrast, our hypoparathyroid thalassemic patients did not have elevated FGF-23 levels. A previous study reported that excessive iron disturbed the metabolism of mouse osteoblastic cells (17). In addition, ferric iron was shown to inhibit osteoblast proliferation, differentiation and mineralization. Moreover, the inhibition of human osteoblast activity was concentration-dependent (18). Iron overload inevitably occurs in transfusion-dependent thalassemic patients and iron accumulation in thalassemic bones has also been demonstrated (16,33). Thus, FGF23 production by osteoblasts and osteocytes could be compromised in thalassemic patients. Our study showed that plasma intact FGF-23 level was significantly higher in the controls as compared with the thalassemic group. This finding could reflect an impaired FGF-23 production among thalassemic patients. Median plasma FGF-23 level in patients with hypoparathyroidism was significantly lower than that of normoparathyroid patients (34.8 vs $43.1 \mathrm{pg} / \mathrm{mL}, \mathrm{p}=0.048$ ) although serum $P$ levels and serum PTH levels were comparable. These findings suggest that FGF-23 response in patients with hypoparathyroidism might be impaired. One would expect to see elevated serum P levels in these hypoparathyroid patients because of impairment of both phosphaturic hormones, PTH and FGF-23. The reason for an absence of elevated serum $P$ in these patients is unclear and merits further investigation.

Iron deficiency, an opposite condition to iron overload state, has been reported to be associated with elevated serum FGF-23 levels in patients with autosomal dominant hypophosphatemic rickets (ADHR), in the elderly population and in undernourished Gambian children $(34,35,36)$. In addition, iron deficiency upregulated Fgf23 mRNA in bones of Fgf23 knock-in mice and consequently led to an ADHR phenotype (37). Improvement of iron status following iron supplementation was associated with a decrease in serum FGF-23 level in undernourished Gambian children and patients with ADHR $(36,38)$. Moreover, the latter had a complete loss of biochemical ADHR phenotype following iron supplementation (38). The mechanism of iron status in influencing FGF-23 concentration remains to be elucidated. However, to our knowledge, the impact of an iron overload state on FGF-23 level, secondary to thalassemia or hereditary hemochromatosis, has not been reported. One might speculate that an iron overload leads to a decrease in FGF-23 production in an opposite direction to the effect of iron deficiency. Our previous study demonstrated "iron-associated focal osteomalacia" in bone histology of patients with thalassemia (16). Osteoblasts and osteocytes could be disturbed by iron accumulation in bones and thus lead to impaired FGF-23 production. Further studies are required to assess the effects of iron overload on the synthesis, secretion and metabolism of FGF- 23.

\section{Study Limitations}

There were some limitations of this study. First, the sample size was relatively small. Second, the control and thalassemic groups were not matched for age and pubertal maturation level. However, previous studies reported no age- and puberty-associated changes in FGF23 levels $(39,40)$. Third, serum 1.25- $(\mathrm{OH})_{2}$ vitamin D was not measured. Thus, pathophysiological changes of serum 1.25- $(\mathrm{OH})_{2}$ vitamin D related to plasma FGF-23 during hypoparathyroidism or normoparathyroidism could not be assessed.

\section{Conclusion}

Hypoparathyroidism was not uncommon in patients with transfusion-dependent thalassemia treated with suboptimal iron chelation. Plasma FGF-23 level in patients with hypoparathyroidism was lower than that of patients with normoparathyroidism. 


\section{Acknowledgements}

This study was supported by the research grant from the Faculty of Medicine Ramathibodi Hospital, Mahidol University, Bangkok, Thailand.

\section{Ethics}

Ethics Committee Approval: The study was approved by the Ethics Committee of the Faculty of Medicine Ramathibodi Hospital, Mahidol University (ethics approval no. MURA2013/24 Np1).

Informed Consent: Informed consent was obtained from the patients and their legal guardians.

Peer-review: Externally and internally peer-reviewed.

\section{Authorship Contributions}

Concept: Pat Mahachoklertwattana, Hataitip Tangngam, Preamrudee Poomthavorn, Ampaiwan Chuansumrit, Data Collection or Processing: Pat Mahachoklertwattana, Hataitip Tangngam, Preamrudee Poomthavorn, Ampaiwan Chuansumrit, Nongnuch Sirachainan, La-or Chailurkit, Patcharin Khlairit, Analysis or Interpretation: Pat Mahachoklertwattana, Hataitip Tangngam, Preamrudee Poomthavorn, Ampaiwan Chuansumrit, Nongnuch Sirachainan, La-or Chailurkit, Patcharin Khlairit, Literature Search: Pat Mahachoklertwattana, Hataitip Tangngam, Preamrudee Poomthavorn, Ampaiwan Chuansumrit, Nongnuch Sirachainan, La-or Chailurkit, Patcharin Khlairit, Writing: Pat Mahachoklertwattana, Hataitip Tangngam, Preamrudee Poomthavorn, Ampaiwan Chuansumrit.

Financial Disclosure: Research grant from the Faculty of Medicine, Ramathibodi Hospital, Mahidol University, Bangkok, Thailand.

\section{References}

1. Vogiatzi MG, Macklin EA, Trachtenberg FL, Fung EB, Cheung AM, Vichinsky E, Olivieri N, Kirby M, Kwiatkowski JL, Cunningham M, Holm IA, Fleisher M, Grady RW, Peterson CM, Giardina PJ; Thalassemia Clinical Research Network. Differences in the prevalence of growth, endocrine and vitamin D abnormalities among the various thalassaemia syndromes in North America. Br J Haematol 2009;146:546-556. Epub 2009 Jul 13

2. Even L, Bader T, Hochberg Z. Nocturnal calcium, phosphorus and parathyroid hormone in the diagnosis of concealed and subclinical hypoparathyroidism. Eur J Endocrinol 2007;156:113-116.

3. Sleem GA, Al-Zakwani IS, Almuslahi M. Hypoparathyroidism in adult patients with beta-thalassemia major. Sultan Qaboos Univ Med J 2007;7:215-218

4. Zandian KM, Mohammadian Nasab AM, Riahy K, Shahbazian $\mathrm{H}$, Khoshhal DF, Ashrafi MR, Salajaghah N. The prevalence of hypoparathyroidism among patients with major thalassemia aged above 10 years. Iran J Pediatr 2005;15:157-164.
5. Gamberini MR, De Sanctis V, Gilli G. Hypogonadism, diabetes mellitus, hypothyroidism, hypoparathyroidism: incidence and prevalence related to iron overload and chelation therapy in patients with thalassaemia major followed from 1980 to 2007 in the Ferrara Centre. Pediatr Endocrinol Rev 2008;6(Suppl 1):158-169.

6. Belhoul KM, Bakir ML, Saned MS, Kadhim AM, Musallam KM, Taher AT. Serum ferritin levels and endocrinopathy in medically treated patients with $\beta$ thalassemia major. Ann Hematol 2012;91:1107-1114. Epub 2012 Jan 28

7. Pirinççioğlu AG, Akpolat V, Köksal O, Haspolat K, Söker M. Bone mineral density in children with beta-thalassemia major in Diyarbakir. Bone 2011;49:819-823. Epub 2011 Jul 23

8. Mula-Abed WA, Al-Hashmi HS, Al-Muslahi MN. Indicators of renal glomerular and tubular functions in patients with beta-thalassemia major: a cross sectional study at the Royal Hospital, Oman. Sultan Qaboos Univ Med J 2011;11:69-76. Epub 2011 Feb 12

9. Aldudak B, Bayazit A, Noyan A, Ozel A, Anarat A, Sasmaz I, Kilinc Y, Gali E, Anarat R, Dikmen N. Renal function in pediatric patients with $\beta$-thalassemia major. Pediatr Nephrol 2000;15:109-112.

10. Mahachoklertwattana P, Pootrakul P, Chuansumrit A, Choubtum L, Sriphrapradang A, Sirisriro R, Rajatanavin R. Association between bone mineral density and erythropoiesis in Thai children and adolescents with thalassemia syndromes. J Bone Miner Metab 2006;24:146-152.

11. Mahachoklertwattana P, Chuansumrit A, Sirisriro R, Choubtum L, Sriphrapradang A, Rajatanavin R. Bone mineral density, biochemical and hormonal profiles in suboptimally treated children and adolescents with beta-thalassemia disease. Clin Endocrinol (Oxf) 2003;58:273279.

12. Shamshirsaz AA, Bekheirnia MR, Kamgar M, Pourzahedgilani N, Bouzari N, Habibzadeh M, Hashemi R, Shamshirsaz AA, Aghakhani S, Homayoun H, Larijani B. Metabolic and endocrinologic complications in beta-thalassemia major: a multicenter study in Tehran. BMC Endocr Disord 2003;3:4.

13. Kumar R. Phosphate sensing. Curr Opin Nephrol Hypertens 2009;18:281-284.

14. Saito H, Kusano K, Kinosaki M, Ito H, Hirata M, Segawa H, Miyamoto K, Fukushima N. Human fibroblast growth factor-23 mutants suppress $\mathrm{Na}+$-dependent phosphate co-transport activity and 1.25-dihydroxyvitamin D3 production. J Biol Chem 2003;278:22062211. Epub 2002 Nov 4.

15. Ben-Dov IZ, Galitzer H, Lavi-Moshayoff V, Goetz R, Kuro-o M, Mohammadi M, Sirkis R, Naveh-Many T, Silver J. The parathyroid is a target organ for FGF23 in rats. J Clin Invest 2007;117:4003-4008.

16. Mahachoklertwattana P, Sirikulchayanonta V, Chuansumrit A, Karnsombat P, Choubtum L, Sriphrapradang A, Domrongkitchaiporn S, Sirisriro R, Rajatanavin R. Bone histomorphometry in children and adolescents with beta-thalassemia disease: iron-associated focal osteomalacia. J Clin Endocrinol Metab 2003;88:3966-3972.

17. Yamasaki K, Hagiwara H. Excess iron inhibits osteoblast metabolism. Toxicol Lett 2009;191:211-215. Epub 2009 Sep 6

18. Zhao GY, Zhao LP, He YF, Li GF, Gao C, Li K, Xu YJ. A comparison of the biological activities of human osteoblast hFOB1.19 between iron excess and iron deficiency. Biol Trace Elem Res 2012;150:487-495. Epub 2012 Oct 10

19. Porter JB, Davis BA. Monitoring chelation therapy to achieve optimal outcome in the treatment of thalassaemia. Best Pract Res Clin Haematol 2002;15:329-368.

20. Alon U, Hellerstein S. Assessment and interpretation of the tubular threshold for phosphate in infants and children. Pediatr Nephrol 1994;8:250-251. 
21. Canatan D. The Thalassemia Center of Antalya State Hospital: 15 years of experience (1994 to 2008). J Pediatr Hematol Oncol 2013;35:24-27.

22. Mostafavi H, Afkhamizadeh M, Rezvanfar MR. Endocrine disorders in patients with thalassemia major. Iran J Endocrinol Metab 2005;7:143147.

23. Adil A, Sobani ZA, Jabbar A, Adil SN, Awan S. Endocrine complications in patients of beta thalassemia major in a tertiary care hospital in Pakistan. J Pak Med Assoc 2012;62:307-310.

24. Angelopoulos NG, Goula A, Rombopoulos G, Kaltzidou V, Katounda E, Kaltsas D, Tolis G. Hypoparathyroidism in transfusion-dependent patients with beta-thalassemia. J Bone Miner Metab 2006;24:138-145.

25. Basha N KP, Shetty B, Shenoy UV. Prevalence of hypoparathyroidism (HPT) in beta thalassemia major. J Clin Diagn Res 2014;8:24-26. Epub 2014 Feb 3

26. De Sanctis V, Vullo C, Bagni B, Chiccoli L. Hypoparathyroidism in betathalassemia major. Clinical and laboratory observations in 24 patients. Acta Haematol 1992;88:105-108.

27. Porter J, Viprakasit V. Chapter 3. Iron overload and chelation. In Cappellini MD, Cohen A, Porter J, Taher A, Viprakasit V (eds). Guidelines for the management of transfusion dependent thalassemia (TDT) 3 rd ed. Thalassemia International Federation. Nicosia, Cyprus, 2014;4243.

28. Mohammadian S, Bazrafshan HR, Sadeghi-Nejad A. Endocrine gland abnormalities in thalassemia major: a brief review. J Pediatr Endocrinol Metab 2003;16:957-964.

29. Habeb AM, Al-Hawsawi ZM, Morsy MM, Al-Harbi AM, Osilan AS, AlMagamsi MS, Zolaly MA. Endocrinopathies in beta-thalassemia major. Prevalence, risk factors, and age at diagnosis in Northwest Saudi Arabia. Saudi Med J 2013;34:67-73.

30. Liao SC, Moi SH, Chou FF, Yang $\mathrm{CH}$, Chen JB. Changes in serum concentrations of fibroblast growth factor 23 and soluble Klotho in hemodialysis patients after total parathyroidectomy. Biomed Res Int 2016;2016:6453803. Epub 2016 Nov 24

31. Yamashita H, Yamazaki Y, Hasegawa H, Yamashita T, Fukumoto S, Shigematsu T, Kazama JJ, Fukagawa M, Noguchi S. Fibroblast growth factor-23 (FGF23) in patients with transient hypoparathyroidism: its important role in serum phosphate regulation. Endocr J 2007;54:465470. Epub 2007 Apr 27

32. Bech A, Nabbe K, Brussel W, Telting D, de Boer H. Elevated fibroblast growth factor 23 levels in a newborn with secondary hypoparathyroidism. Pediatrics 2010;126:1613-1616. Epub 2010 Nov

33. Rioja L, Girot R, Garabédian M, Cournot-Witmer G. Bone disease in children with homozygous beta-thalassemia. Bone Miner 1990;8:6986.

34. Imel EA, Peacock M, Gray AK, Padgett LR, Hui SL, Econs MJ. Iron modifies plasma FGF23 differently in autosomal dominant hypophosphatemic rickets and healthy humans. J Clin Endocrinol Metab 2011;96:3541-3549. Epub 2011 Aug 31

35. Bozentowicz-Wikarek M, Kocelak P, Owczarek A, OlszaneckaGlinianowicz M, Mossakowska M, Skalska A, Wiecek A, Chudek J. Plasma fibroblast growth factor 23 concentration and iron status. Does the relationship exist in the elderly population? Clin Biochem 2015;48:431-436. Epub 2015 Jan 9.

36. Braithwaite V, Prentice AM, Doherty C, Prentice A. FGF23 is correlated with iron status but not with inflammation and decreases after iron supplementation: a supplementation study. Int J Pediatr Endocrinol 2012;2012:27

37. Farrow EG, Yu X, Summers LJ, Davis SI, Fleet JC, Allen MR, Robling AG, Stayrook KR, Jideonwo V, Magers MJ, Garringer HJ, Vidal R, Chan RJ, Goodwin CB, Hui SL, Peacock M, White KE. Iron deficiency drives an autosomal dominant hypophosphatemic rickets (ADHR) phenotype in fibroblast growth factor-23 (Fgf23) knock-in mice. Proc Natl Acad Sci USA 2011;108:1146-1155. Epub 2011 Oct 17

38. Kapelari K, Köhle J, Kotzot D, Högler W. Iron supplementation associated with loss of phenotype in autosomal dominant hypophosphatemic rickets. J Clin Endocrinol Metab 2015;100:3388-3392.

39. Gkentzi D, Efthymiadou A, Kritikou D, Chrysis D. Fibroblast growth factor 23 and klotho serum levels in healthy children. Bone 2014;66:814. Epub 2014 May 29

40. Mitchell DM, Juppner H, Burnett-Bowie SM. FGF23 is not associated with age-related changes in phosphate, but enhances renal calcium reabsorption in girls. J Clin Endocrinol Metab 2017;102:1151-1160. 